\title{
Impact of Land Rental Market Participation on Smallholder Farmers' Commercialization: Panel Data Evidence from Northern Ethiopia - CORRIGENDUM
}

\author{
Menasbo Gebru Tesfay
}

Keywords: Commercialization; correlated random effects; Ethiopia; land rental market; Tigrai; corrigendum

In the original publication of this article, an incorrect word was mistakenly used in the abstract. The article has been updated with the correct abstract phrasing. The author apologizes for this error.

\section{Reference}

Tesfay, M.G. "Impact of Land Rental Market Participation on Smallholder Farmers' Commercialization: Panel Data Evidence from Northern Ethiopia." Journal of Agricultural and Applied Economics 52,4(2020):580-595. https://doi.org/10.1017/aae. 2020.19

\footnotetext{
Cite this article: Tesfay MG (2020). Impact of Land Rental Market Participation on Smallholder Farmers' Commercialization: Panel Data Evidence from Northern Ethiopia - CORRIGENDUM. Journal of Agricultural and Applied Economics 52, 664. https://doi.org/10.1017/aae.2020.28

( ) The Author 2020. This is an Open Access article, distributed under the terms of the Creative Commons Attribution-NonCommercialShareAlike licence (http://creativecommons.org/licenses/by-nc-sa/4.0/), which permits non-commercial re-use, distribution, and reproduction in any medium, provided the same Creative Commons licence is included and the original work is properly cited. The written permission of Cambridge University Press must be obtained for commercial re-use.
} 